\title{
Effects of Selected Root Exudate Components on Nitrogen Removal and Development of Denitrifying Bacteria in Constructed Wetlands
}

\author{
Hailu Wu, Xinze Wang * and Xiaojuan He * \\ School of Environmental Science and Engineering, Shanghai Jiao Tong University, Shanghai 200240, China; \\ wuhailu@sjtu.edu.cn. \\ * Correspondence: xinzewang@sjtu.edu.cn (X.W.); hexiaojuan@sjtu.edu.cn (X.H.); \\ Tel.: +86-21-5474-4540 (X.W. \& X.H.)
}

Received: 26 March 2017; Accepted: 10 June 2017; Published: 14 June 2017

\begin{abstract}
Root exudates, particularly low molecular weight carbon (LMWC) substrates, are major drivers of bacterial diversity and activity in the rhizosphere environment. However, it is not well understood how specific LMWC compounds-such as organic acids, soluble sugars, and amino acids-influence the community structures of denitrifying bacteria or if there are specific functions of LMWC substrates that preferentially respond to nitrogen $(\mathrm{N})$ removal in constructed wetlands (CWs). To address these knowledge gaps, we added mixtures of artificial exudates to CW microcosms containing $\mathrm{N}$ pollutant. $\mathrm{N}$ removal efficiency was observed over a 48 -h experimental period, and at the end of the experiment, DNA was extracted from microbial samples for assessment of the bacterial community. The removal efficiencies of $\mathrm{TN}$ for the exudates treatments were higher than for control groups by $47.1-58.67 \%$. Organic acid and soluble sugar treatments increased $\mathrm{N}$ removal, while amino acids were negative to $\mathrm{N}$ removal. The microbial community was changed when artificial exudates were added, but there were no significant relationships between LMWC compounds and bacterial community composition. These results indicate that although the responses of community structures of denitrifying bacteria to LMWC additions are still uncertain, there is evidence for $\mathrm{N}$ removal in response to exudate additions across LMWC types.
\end{abstract}

Keywords: exudate; low molecular weight carbon; constructed wetland; $\mathrm{N}$ removal; denitrifying bacteria

\section{Introduction}

Nitrogen $(\mathrm{N})$ compounds deriving from agricultural fertilizers and livestock manure can contaminate surface water, resulting in eutrophication [1]. Constructed wetlands (CWs) have been widely built as a cost-efficient remediation technology for $\mathrm{N}$ removal [2,3]. Nitrification-denitrification is the dominant process for $\mathrm{N}$ removal in CWs, where all forms of $\mathrm{N}$ tend to transform into $\mathrm{NO}_{3}{ }^{-}{ }^{-} \mathrm{N}$ and are subsequently lost from the system due to denitrification. Hence, denitrification is the critical process in preventing water eutrophication in CWs. Most denitrification is accomplished by heterotrophic bacteria, and the process is strongly dependent on carbon $(C)$ availability. There is a general correlation between denitrification being restricted or inhibited by lack of organic $\mathrm{C}$ in CWs [4,5]. In traditional wastewater treatment systems, heterotrophic denitrification is often applied using external electron and $C$ donors (for example, carbohydrates or organic alcohols) when endogenous organic donors originating from the waste are insufficient [6,7]. There are many kinds of aquatic plants in CWs, and these may deliver low molecular weight carbon (LMWC) substrates via root exudates to fuel microbial denitrification [8].

Many studies dedicated to comparing microbial community structures originating from different rhizospheres in CWs have suggested that differences in plants were partly responsible for divergences 
in the structures of microbial communities, which differ quantitatively and qualitatively with plant developmental stage and root location $[9,10]$. These results might be interpreted as signs of root exudate diversity and availability. Microbial denitrification in response to root exudates has also been studied by many researchers. Salvato et al. [11] studied five emergent plant species for the decontamination of $\mathrm{N}$-polluted water at the mesoscale level; they found that root exudates of Typha arundinacea and Phragmites australis exhibited a higher production of water-soluble $\mathrm{C}$ and achieved the highest denitrification percentages (37\% and 34\%, respectively). Huang et al. [12] found that the removal efficiencies of $\mathrm{COD}, \mathrm{NH}_{4}{ }^{+}, \mathrm{TN}$, and TP by Cyperus alternifolius were higher than those of Canna indica (per unit weight) and were significantly associated with root secretion and radial oxygen loss.

To build on these previous studies, it is important to elucidate the availability of root exudates, particularly their effects on $\mathrm{N}$ removal and their response to denitrifying bacteria communities in $\mathrm{CW}$. Despite more and more work related to exudates, key knowledge gaps remain, as most previous C-addition studies have used only a single substrate (e.g., acetate or methanol [13]) or an undefined plant exudate (e.g., ryegrass root exudate [14]). We have limited understanding of bacterial community shifts associated with the addition of specific $C$ substrates. To the best of our knowledge, there are not any studies aimed directly at demonstrating the involvement of exudates in community structures of denitrifying bacteria in CWs. Current understanding of how the quality and amount of root exudates affect denitrifying microorganisms in CWs is insufficient. Denitrification processes are mainly catalyzed by different functional genes, and copper-containing nitrite reductase (nirK) and nitrite reductase (nirS) are the predominant genes, so nirK genes and nirS genes were chosen to evaluate denitifiers in the study.

In this study, we tested whether compositional differences in the inputs of LMWC compounds induce a change in the community of denitrifying bacteria. Three LMWC compounds (sugars, organic acids, and amino acids) which have often been described as root exudates were applied to CWs $[15,16]$. After 30 days, nirK- and nirS-encoding denitrifying bacteria were detected by illumina high-throughput sequencing and real-time PCR. The main objectives of this paper were as follows: (I) to assess the influence of artificial root exudates (ARE) on $\mathrm{N}$ removal in CWs; (II) to assess the development of nir-encoding denitrifying bacteria when influenced by artificial exudates; (III) to evaluate the potential contribution of different $C$ substrates as organic $C$ sources for denitrificaiton in CWs.

\section{Materials and Methods}

\subsection{Experimental Design}

We set up laboratory-scale CWs using polyethylene barrels (inner diameter, $25 \mathrm{~cm}$; height, $40 \mathrm{~cm}$ ). All the CWs were filled with washed gravel (mainly $\mathrm{Si}_{2} \mathrm{O}_{3}$ and $\mathrm{Al}_{2} \mathrm{O}_{3}, 1 \mathrm{~cm}$ in diameter) as a substrate to a depth of $25 \mathrm{~cm}$. Prior to use, the gravel was sterilized by alcohol to exclude any possible microbial biomass and diversity. A stopper was set at the bottom of barrel to collect effluents. Synthetic wastewater was prepared using $\left(\mathrm{NH}_{4}\right)_{2} \mathrm{SO}_{4}, \mathrm{KH}_{2} \mathrm{PO}_{4}$ and $\mathrm{KNO}_{3}$. The water depth was kept $1 \mathrm{~cm}$ above the gravel surface. A sequencing fill-and-draw batch mode was applied to the influent. The characteristics of the influent water were as follows: TN was $9.2 \mathrm{mg} \mathrm{L}^{-1}$, ammonium $\left(\mathrm{NH}_{4}{ }^{+}-\mathrm{N}\right)$ was $3 \mathrm{mg} \mathrm{L}^{-1}$, nitrate nitrogen $\left(\mathrm{NO}_{3}{ }^{-}-\mathrm{N}\right)$ was $6 \mathrm{mg} \mathrm{L}^{-1}, \mathrm{pH}$ was 7.0 , dissolved oxygen (DO) was $8.0 \mathrm{mg} \mathrm{L}^{-1}$, the hydraulic load was $0.1 \mathrm{~m}^{3} \mathrm{~m}^{-2} \mathrm{batch}^{-1}$, and the hydraulic retention time was two days. The ambient temperature during the experiment was $20^{\circ} \mathrm{C}$.

At the start of experiment, unidentified denitrifying bacteria were enriched from wetland soil by bacterial culture medium. Barrels were inoculated with $1 \%$ (volume ratio) of pre-incubated microbe. After acclimation for four weeks, biofilm attached on the gravel indicated microbes in the CWs were flourishing. At that point, ARE-LMWC substrates were added with influent water for 15 periods (30 days). To test for the effects of root exudate diversity, we created four artificial exudates mixtures: ARE, Glu(-), Org(-), and Ami(-). All the exudate treatments contained the same C concentration but 
different compounds (Table 1), while the control treatment (Con) consisted of only deionized water. Overall, we set up $15 \mathrm{CWs}$ (five different exudate treatments $\times$ three replicates).

Table 1. Composition of supply LMWC solution concentration.

\begin{tabular}{|c|c|c|c|c|c|}
\hline Treatment & Sugars $\left(\mathrm{g} \mathrm{L}^{-1}\right)$ & Organic Acids $\left(\mathrm{g} \mathrm{L}^{-1}\right)$ & Amino Acid $\left(\mathrm{mg} \mathrm{L}^{-1}\right)$ & $\begin{array}{l}\text { C input } \\
\left(\mathrm{g} \mathrm{L}^{-1}\right)\end{array}$ & $\begin{array}{r}\text { N Input } \\
\left(\mathrm{mg} \mathrm{L}^{-1}\right)\end{array}$ \\
\hline Con & 0 & 0 & 0 & 0 & 0 \\
\hline ARE & $\begin{array}{l}\text { Glucose-0.637 } \\
\text { Sucrose- } 0.624\end{array}$ & $\begin{array}{l}\text { Tartaric acid- } 0.704 \\
\text { Succinic acid-0.633 }\end{array}$ & $\begin{array}{l}\text { Serine- } 0.5 \text { glutamate- } 0.5 \\
\text { alanine- } 0.5\end{array}$ & 1 & 0.2 \\
\hline Glu(-) & 0 & $\begin{array}{r}\text { Tartaric acid-1.513 } \\
\text { Succinic acid-1.269 }\end{array}$ & $\begin{array}{c}\text { Serine- } 0.5 \text { glutamate- } 0.5 \\
\text { alanine- } 0.5\end{array}$ & 1 & 0.2 \\
\hline $\operatorname{Org}(-)$ & $\begin{array}{l}\text { Glucose-1.241 } \\
\text { Sucrose-1.197 }\end{array}$ & 0 & $\begin{array}{c}\text { Serine- } 0.5 \text { glutamate- } 0.5 \\
\text { alanine- } 0.5\end{array}$ & 1 & 0.2 \\
\hline Ami(-) & $\begin{array}{l}\text { Glucose- } 0.637 \\
\text { Sucrose- } 0.624\end{array}$ & $\begin{array}{l}\text { Tartaric acid- } 0.704 \\
\text { Succinic acid- } 0.633\end{array}$ & 0 & 1 & 0 \\
\hline
\end{tabular}

\subsection{Sampling and Water Quality Analysis}

In the 15th period of the experiment, water samples in the CWs were collected every $2 \mathrm{~h}$ up to $12 \mathrm{~h}$, and subsequently at 24 and $48 \mathrm{~h}$. Samples were filtered through a $0.45 \mu \mathrm{m}$ pore size mixed-cellulose-ester membrane filter (Sangon Biotech, Shanghai, China) and analyzed for $\mathrm{NH}_{4}{ }^{+}-\mathrm{N}$, $\mathrm{NO}_{3}{ }^{-}-\mathrm{N}$, nitrite nitrogen $\left(\mathrm{NO}_{2}{ }^{-}-\mathrm{N}\right)$, and $\mathrm{TN}$ using a flow injection analysis instrument (QC8500, Hach, Loveland, CO, USA). DO were measured by a DO Meter (HQ30d, Hach, Loveland, CO, USA) in situ in accordance with the sampling time. After $48 \mathrm{~h}$, water samples were collected to analyze organic acids and sugars using a high-performance liquid chromatography (HPLC) analyzer (Waters2690, Miford, MA, USA). The HPLC procedures and analytical materials followed the procedure described by Wu et al. [17]. After 30 days, $10 \mathrm{~g}$ of gravel from each CW was dropped into a conical flask containing $150 \mathrm{~mL}$ deionized water. All the flasks were placed on an orbital shaker (120 rpm) for $10 \mathrm{~min}$ and centrifuged $\left(8000 \mathrm{rpm}, 5 \mathrm{~min},-20^{\circ} \mathrm{C}\right)$. The precipitates from the flask were used for subsequent community DNA extractions.

\subsection{DNA Extraction and qPCR Analysis}

The total genomic DNA of each sample was extracted directly from the membranes using the PowerSoil DNA Isolation Kit (MIOBIO Laboratories) according to the manufacturer's instructions. Extracted genomic DNA was detected using $1.2 \%$ agarose gel electrophoresis and stored at $-20{ }^{\circ} \mathrm{C}$ until further processing.

A Funglyn Biotech FTC-3000 real-time PCR system (Canada) was used to quantify the nirK genes using primers $\mathrm{F} 1 \mathrm{aCu}\left(5^{\prime}\right.$-ATCATGGTSCTGCCGCG-3')/ $\mathrm{R} 3 \mathrm{Cu}\left(5^{\prime}\right.$-GCCTCGATCAGRTTGTGGTT-3'). The nirS genes were quantified with primers $\mathrm{cd} 3 \mathrm{aF}\left(5^{\prime}\right.$-GTSAACGTSAAGGARACSGG-3')/R3cd ( $5^{\prime}$-GASTTCGGRTGSGTCTTGA- $3^{\prime}$ ). The total amount of the reaction mixture was $25 \mu \mathrm{L}$, comprising $12.5 \mu \mathrm{L}$ of SYBR Premix Ex TaqTMII (Takara, Japan), $5 \mu \mathrm{L}$ of template DNA (1-10 ng), and $0.3 \mu \mathrm{L}$ or $1.0 \mu \mathrm{L}$ of forward and reverse primers $(10 \mathrm{mM})$ for the nirK genes and nirS genes, respectively; nuclease-free water was added to yield a total of $25 \mu \mathrm{L}$. The qPCR cycles were as follows: $10 \mathrm{~min}$ at $95^{\circ} \mathrm{C}$ and 40 cycles of $10 \mathrm{~s}$ at $95^{\circ} \mathrm{C}, 30 \mathrm{~s}$ at $55^{\circ} \mathrm{C}$, and $30 \mathrm{~s}$ at $72^{\circ} \mathrm{C}$. The threshold cycles (Ct) obtained in each PCR run were compared with those of the known standard DNA concentrations, and the expression of a glyceraldehyde 3-phosphate dehydrogenase (GAPDH) was used as the endogenous control to normalize the array. Standard curves were obtained following the procedure described by Di et al. [18]. 


\subsection{Illumina High-Throughput Sequencing}

To construct the gene libraries, nirK genes and nirS genes were targeted using the $\mathrm{F} 1 \mathrm{aCu} / \mathrm{R} 3 \mathrm{Cu}$ and $\mathrm{cd} 3 \mathrm{aF} / \mathrm{R} 3 \mathrm{~cd}$ primer sets. The DNA was extracted, and yields were measured by Illumina MiSeq2*300bp (Illumina, San Diego, CA, USA). The Illumina pyrosequencing was performed at TinyGene Biotech Co. (Shanghai, China). Sequences that were shorter than 250 base pairs (bp) and with a quality score lower than 30 were removed from the data sets, and sequence clustering into operational taxonomic units (OTUs) was performed with USEARCH software (v8.1.1756) at a sequence identity of $97 \%$ using the UCHIME algorithm (v4.2.40) [19]. Chao richness, ACE richness, Shannon diversity, and Simpson diversity were calculated by Mothur analysis at a distance level of $3 \%[9,20]$.

\subsection{Statistical Analysis}

All the data analyses were carried out using Microsoft Excel and an Origin9.1 software package. Each value was the mean value $( \pm \mathrm{SD})$ of three replicates. Statistical analysis was carried out using the SPSS software (version 22, Chicago, IL, USA). One-way ANOVA and post-hoc Tukey's HSD tests were used to compare the degradation efficiency of LMWC substrates and compare the abundance of denitrifying bacteria in the different experiment treatments at the 5\% significance level. Multivariate statistical analysis (redundancy analysis, RDA) conducted by a Canoco software package (Canoco for Windows 4.5, Biometris, Wageningen, The Netherlands) was used to investigate the relationship between key exudates and denitrifying microbes. Significance was assessed based on the mean of a 999 Monte Carlo permutation procedure (1000 unrestricted random permutations; $p<0.05)$ [21].

\section{Results}

\subsection{Pollutant Removal Performance}

Pollutant removal performances of the experimental CWs are shown in Figure 1. DO levels declined over the experiment. It is generally accepted that a DO level above $1.5 \mathrm{mg} \mathrm{L}^{-1}$ is essential for nitrification to occur. For most of the experimental treatments, the level of DO was beneficial to the process of nitrification up to $12 \mathrm{~h}$. The presence of $\mathrm{NH}_{4}{ }^{+}-\mathrm{N}$ decreased during the $48 \mathrm{~h}$ experiment for all treatments. Although the inflow water did not inoculate nitrifying bacteria, the systems were not axenic over the experiment period, suggesting the presence of nitrifying bacteria which had been contributing to nitrification and decreasing $\mathrm{NH}_{4}{ }^{+}-\mathrm{N}$. The removal efficiency of $\mathrm{NH}_{4}{ }^{+}-\mathrm{N}$ in the Control $\mathrm{CW}$ was higher than for CWs treated with LMWC, $3.34 \%$ to $35.28 \%$. This difference may illustrate that artificial exudates inhibit nitrification. The removal efficiency of $\mathrm{NO}_{3}{ }^{-}-\mathrm{N}$ increased for the exudates treatment $\mathrm{CWs}$, contrasting to $15.71 \%$ for the Control group. The $\mathrm{NO}_{3}{ }^{-}-\mathrm{N}$ removal efficiency for exudate-treated groups was $100 \%$ during the 48 -h experiment, while $\mathrm{NO}_{2}{ }^{-}-\mathrm{N}$ levels fluctuated greatly when exudates were added, and because of the weak nitrification there was intense denitrification. The removal efficiency of TN was in accordance with that for $\mathrm{NO}_{3}{ }^{-}-\mathrm{N}$. The removal efficiencies of exudate treatments were higher than control CWs by $47.1-58.67 \%$, indicating that exudates promote denitrification. Furthermore, selected compounds of the exudate mixtures had different pollutant removal efficiencies: the removal efficiency of $\mathrm{NO}_{3}{ }^{-}-\mathrm{N}$ in $\mathrm{Ami}(-)$-treated groups were the fastest, while the changes in removal efficiency were almost synchronous for the ARE, Glu(-), and Org(-) treatments. 


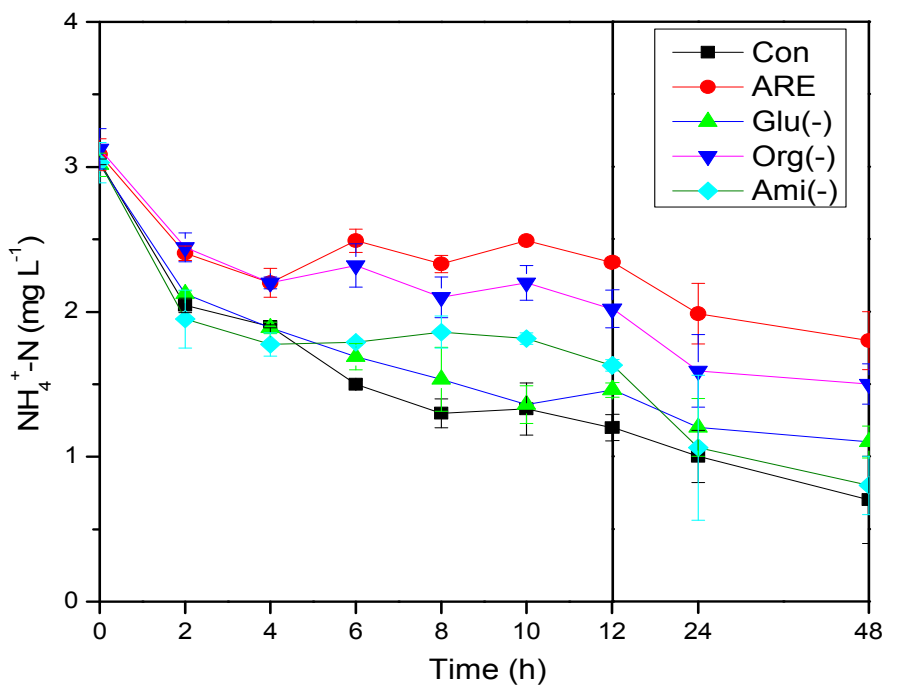

(A)

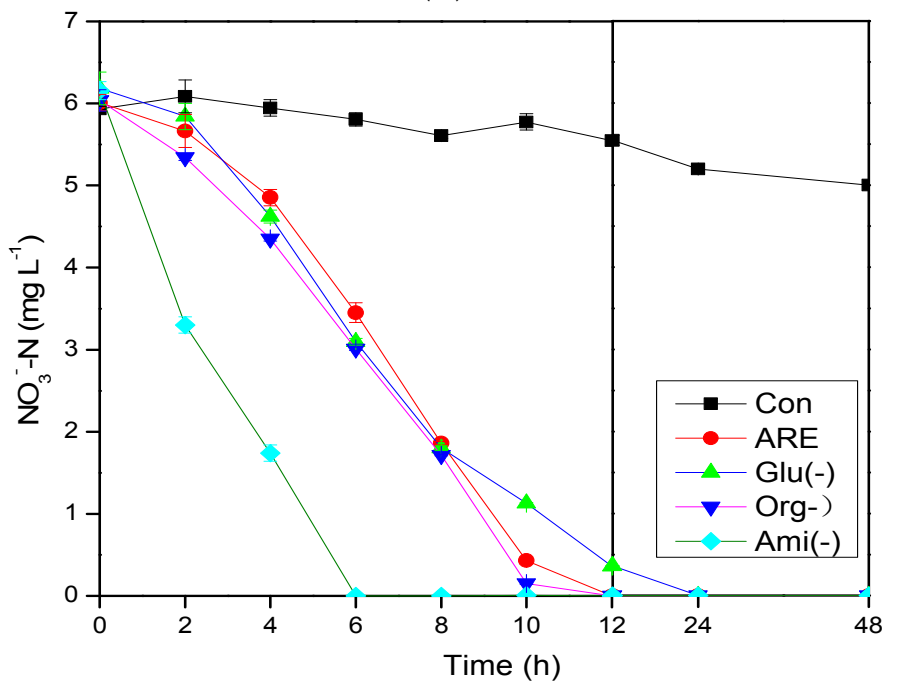

(B)

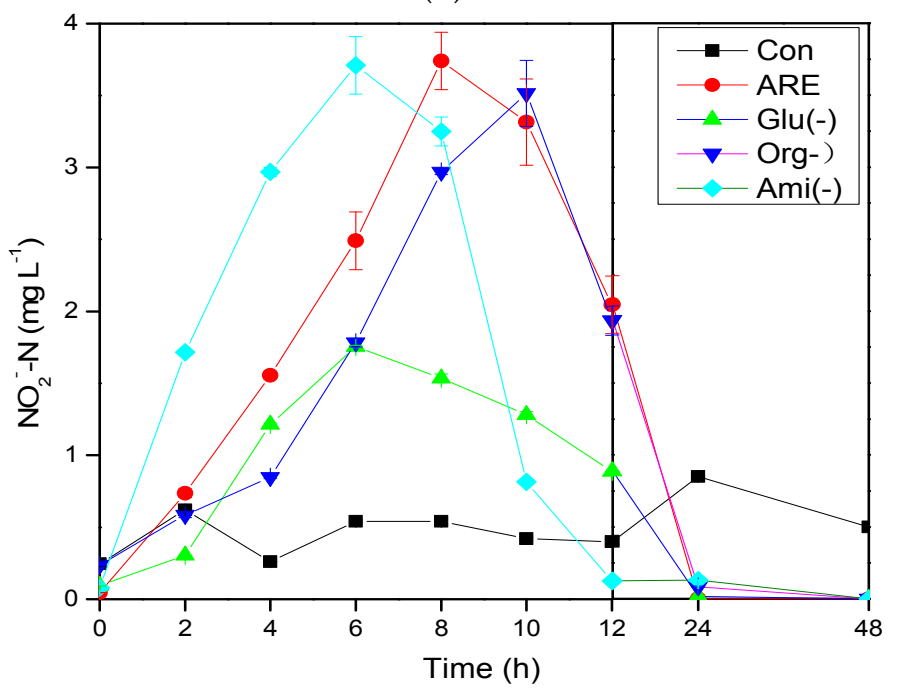

(C)

Figure 1. Cont. 


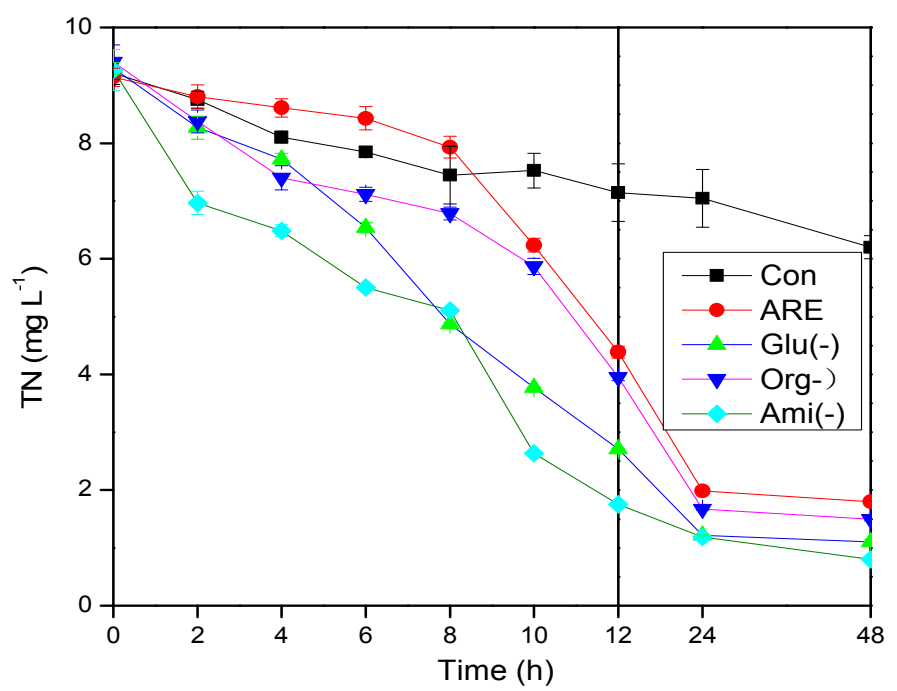

(D)

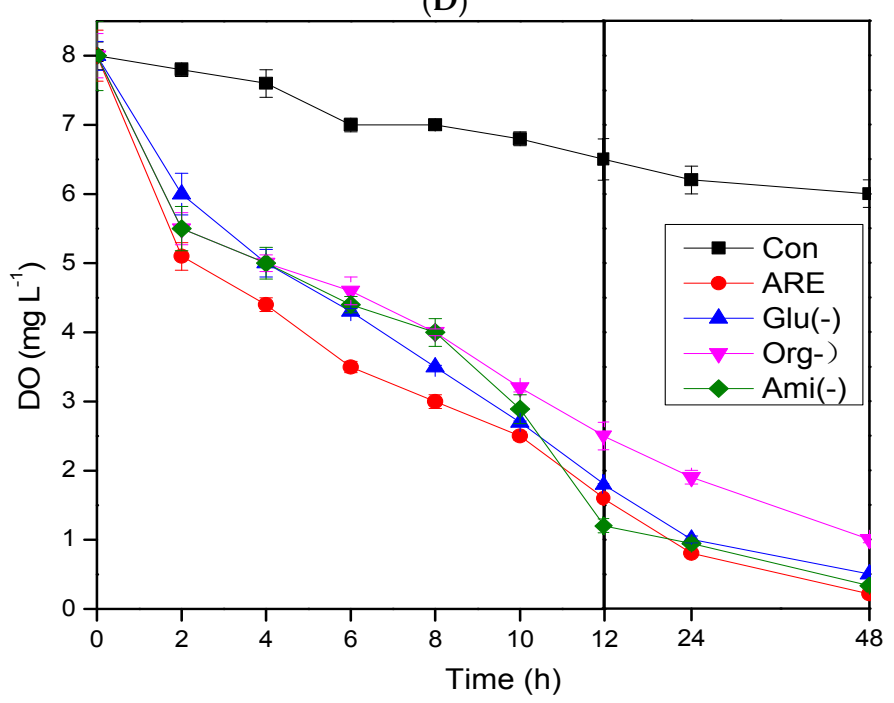

(E)

Figure 1. Average ( \pm sd) concentrations of (A) $\mathrm{NH}_{4}{ }^{+}-\mathrm{N},(\mathbf{B}) \mathrm{NO}_{3}{ }^{-}-\mathrm{N},(\mathbf{C}) \mathrm{NO}_{2}{ }^{-}-\mathrm{N},($ D) $\mathrm{TN}$, and (E) DO in the five different CWs during the 15th period. Con, ARE, Glu(-), Org(-) and Ami(-) were different exudate treatments, symbolic meaning was from Table 1.

\subsection{Quantification of Denitrifying Bacteria}

The abundances of nirK- and nirS-encoding denitrifying bacteria for the different treatments were quantified and are shown in Table 2. Most microbial abundances obtained after exudate treatment were higher than for the control group, which means that the artificial exudates was conducive to microbial growth. The three LMWCs had different effects on microbial abundance, ARE and Glu(-) treatments had significant difference than others between the five different treatments, ARE treatments were most beneficial to denitrifying microbial abundance. The order of gene abundance was ARE $>\operatorname{Glu}(-)>\operatorname{Org}(-)$ $>\operatorname{Ami}(-)>$ Con, the more ingredients in the artificial exudates, the higher the microbial abundance. Besides, when artificial exudates were added, nirK gene abundance increased more obviously than nirS genes, which may illustrate that the artificial exudates had more of an effect on nirK gene abundance than for nirS genes. 
Table 2. The abundance of denitrifying bacteria, by genes of nirS and nirK copies per gram in different CWs (gene copies $\left.\mathrm{g}^{-1}\right)$, values are expressed as means $\pm \mathrm{sd}(n=3)$.

\begin{tabular}{cccccc}
\hline Gene & Con & ARE & Glu(-) & Org(-) & Ami(-) \\
\hline nirK & $8.68 \times 10^{2} \pm 96^{\mathrm{a}}$ & $1.78 \times 10^{5} \pm 8.51 \times 10^{3 \mathrm{c}}$ & $1.46 \times 10^{5} \pm 6.97 \times 10^{4 \mathrm{~b}}$ & $8.29 \times 10^{3} \pm 6.66 \times 10^{2 \mathrm{a}}$ & $1.79 \times 10^{3} \pm 1.27 \times 10^{2 \mathrm{a}}$ \\
nirS & $2.43 \times 10^{3} \pm 2.15 \times 10^{2 \mathrm{a}}$ & $1.75 \times 10^{5} \pm 3.23 \times 10^{4 \mathrm{c}}$ & $6.40 \times 10^{4} \pm 9.21 \times 10^{3 \mathrm{~b}}$ & $6.24 \times 10^{3} \pm 5.69 \times 10^{2 \mathrm{a}}$ & $1.59 \times 10^{3} \pm 2.54 \times 10^{2 \mathrm{a}}$ \\
\hline \multicolumn{5}{c}{ Note: The letters ${ }^{\mathrm{a}, \mathrm{b}}$ and $^{\mathrm{c}}$ indicate significant differences between the five different treatments $(\mathrm{p}<0.05)}$.
\end{tabular}

\subsection{Community Composition of Denitrifying Bacteria}

For this study, a total of 204,281 valid readings for five different treatments were retrieved from the Illumina MiSeq sequencing platform. Each library contained 13,833-31,869 reads (see Table 3), and the coverage values of all plots were higher than $99 \%$. The OTU numbers ranged from 55 to 89 for each sample. Microbial community diversity was analyzed by calculating the Shannon and Simpson diversity index values; higher Shannon index numbers indicated more community diversity. For the nirK gene group, the Shannon index indicated microbial diversity, from highest to lowest: ARE $>\operatorname{Org}(-)>\operatorname{Glu}(-)>$ Ami(-) $>$ Con. For the nirS group, the order was $\operatorname{Org}(-)>\operatorname{Ami}(-)>\operatorname{ARE}>\operatorname{Con}>\mathrm{Glu}(-)$.

Genus-level distributions are shown in Figure 2. Bacteria in the nirK gene group represented 20 different genera, with the dominant genera wildly distributed among different treatments. Paracoccus, Bosea, Enterobacter, Ensifer, and Achromobacter were the dominant genera. Bacteria with nirS genes were identified as representing 27 different genera and accounted for a total of 51.9-93.9\% of all bacterial gene material. Sequences that could not be classified into any known group ranged from $6.1 \%$ to $48.1 \%$, with Paracoccus, Acidovarax, Vogesella, and Dechloromonas the dominant genera. Almost all detected microbial genera were heterotrophic bacteria, and the majority of the bacteria corresponded with those represented in former studies of natural wetlands or CWs.

Table 3. Bacterial taxonomic richness and diversity coverage assessment.

\begin{tabular}{cccccccc}
\hline Gene & Sample & Reads & OTU & Ace Chao & Shannon & Simpson \\
\hline \multirow{6}{*}{ nirK } & Con & 14,720 & 72 & 76 & 77 & 1.96 & 0.2579 \\
& ARE & 31,869 & 86 & 89 & 89 & 2.67 & 0.1064 \\
& Glu(-) & 16,534 & 63 & 69 & 69 & 2.55 & 0.1216 \\
& Org(-) & 13,833 & 68 & 80 & 78 & 2.64 & 0.1211 \\
& Ami(-) & 31,068 & 89 & 91 & 90 & 2.34 & 0.2151 \\
\hline \multirow{6}{*}{ nirS } & Con & 22,229 & 69 & 73 & 73 & 2.49 & 0.1254 \\
& ARE & 22,114 & 72 & 73 & 73 & 2.56 & 0.1452 \\
& Glu(-) & 16,167 & 55 & 57 & 57 & 2.3 & 0.165 \\
& Org(-) & 14,427 & 72 & 78 & 79 & 3.03 & 0.0934 \\
& Ami(-) & 21,320 & 76 & 77 & 77 & 2.96 & 0.0889 \\
\hline
\end{tabular}

Although bacterial community compositions shared similarities, the relative sequence abundance of some genera varied with exudate addition. For the nirK genes, the relative abundance of Paracoccus was predominant, at $73.95 \%$ in the Control CW, but it decreased to $6.52-42.29 \%$ with exudate addition. In contrast, the relative abundance of Bosea and Rhizobium increased by $13.29-47.83 \%$ and $6.83-8.78 \%$, respectively, with exudate addition. Pseudomonas abundance was only $0.05 \%$, and barely changed with the addition of exudates. For the nirS genes, there were many sequences that could not be classified into any known group, ranging from $6.1 \%$ to $48.1 \%$, and the microbe sequences varied irregularly between different treatments. The relative abundance of Azoarcus was $32.47 \%$ in the control group; in contrast, Azoarcus occurred in trace amounts in the exudate-treated groups. Acidovorax and Paracoccus showed opposing changes: the relative abundance of Acidovorax increased in combination with decreasing Paracoccus. Change was absent for the Glu(-)-treated group, a significant difference from other treatments. With this treatment, Zoogloea presence was $20.83 \%$ higher than other genera by $17.65-19.09 \%$. 


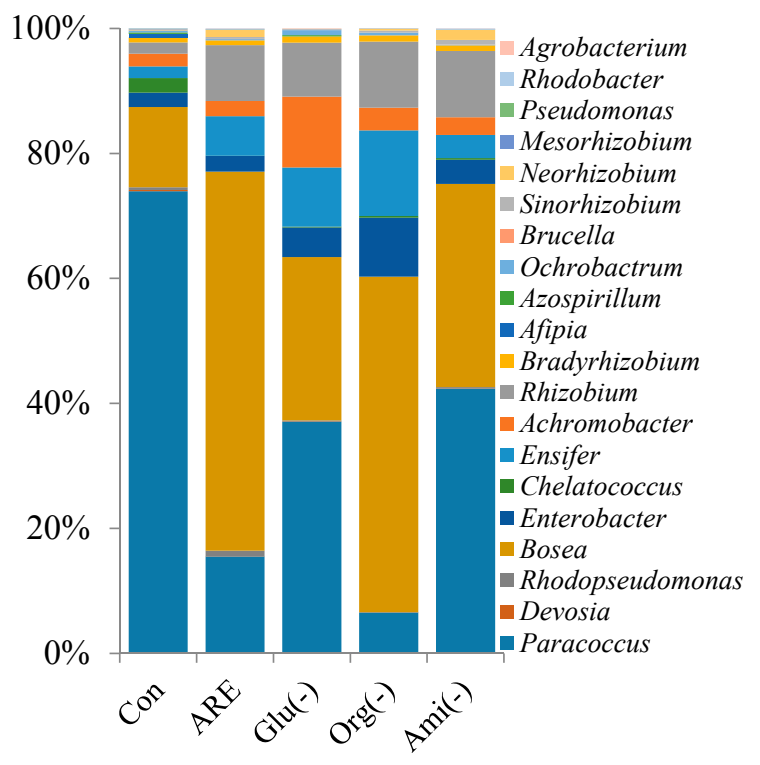

(A)

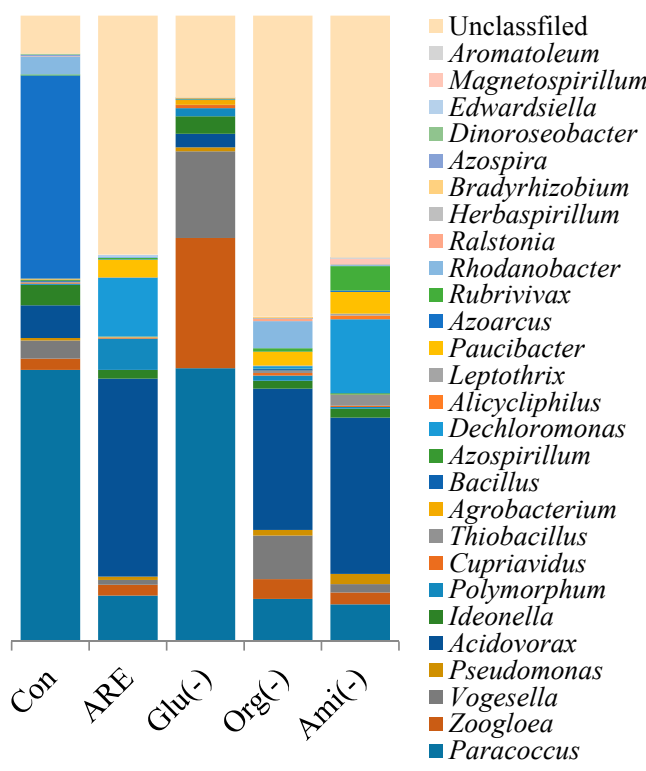

(B)

Figure 2. The community composition of (A) nirK-encoding denitrifying bacteria and (B) nirS-encoding denitrifying bacteria at genus level in CWs.

\subsection{LMWC Substrates Degradation and Their Relevance on Denitrifying Microbes}

Degradation efficiencies of $48 \mathrm{~h}$ artificial exudates are shown in Figure 3. In groups treated with organic acids, the mean removal efficiency of succinic acid differed significantly among the treatments, and tartaric acid had higher degradation efficiency than succinic acid. For sugar-treated groups, mean sucrose and glucose removal efficiencies also differed significantly among the treatments: sucrose had a similar removal efficiency to glucose except for the Ami(-)-treated group, in which the removal efficiency of sucrose was about twice as large as glucose.

The influences of environmental variables on the bacterial communities were analyzed by RDA. Figure 4 show the RDA results for LMWC substrates (organic acids and soluble sugars) and denitrifying communities at the genus level. The first two RDA axes explain more than $95 \%$ of the total variance observed in bacterial community structure. For the nirK genes, succinic acid positively affected Enterobacter and Ensifer; tartaric acid positively affected Achromobacter, Ochrobactrum, and Agrobacterium; and sucrose and glucose positively affected Sinorhizobium, Neorhizobium, and Rhodobacter. Among these microbes, the relative abundances of Ensifer and Achromobacter, predominant microbes in these experiments, were $1.87-13.69 \%$ and $2.01-11.34 \%$, respectively. Therefore, organic acids more strongly affected nirK genes. Meanwhile, for nirS genes, about half of the denitrifying bacteria were positively correlated with sucrose and glucose, and the influence of carbohydrates on nir-genes seemed to be more obvious in nirS genes. We noted that a small percentage of genera responded negatively to the artificial exudates: for instance, Paracoccus was negatively correlated with most LMWC substrates. Moreover, no artificial exudates had a significant effect on the nirS- and nirK-encoding denitrifying bacteria genera in the root rhizosphere $(p>0.05$ by Monte Carlo permutation test). 


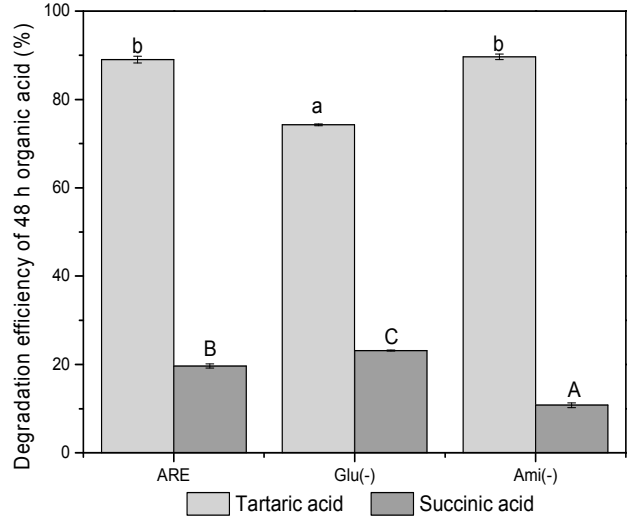

(A)

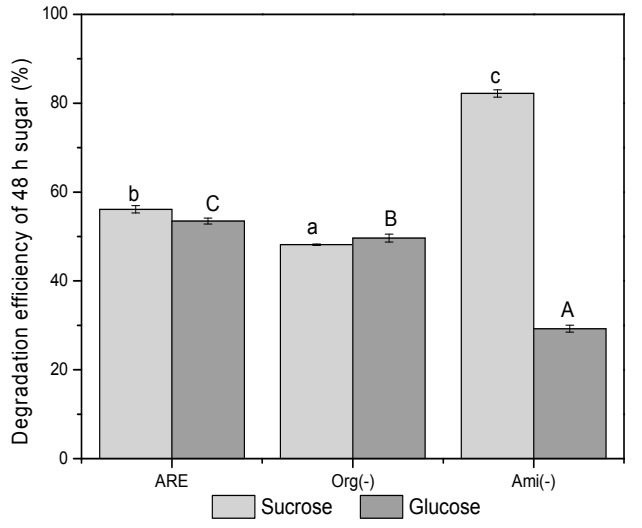

(B)

Figure 3. Mean degradation efficiency of artificial exudates during $48 \mathrm{~h}$ experiments: (A) tartaric acid and succinic acid; (B) sucrose and glucose. A, B, C, and a, b, c, indicate significant differences among the three treatments $(p<0.05)$.
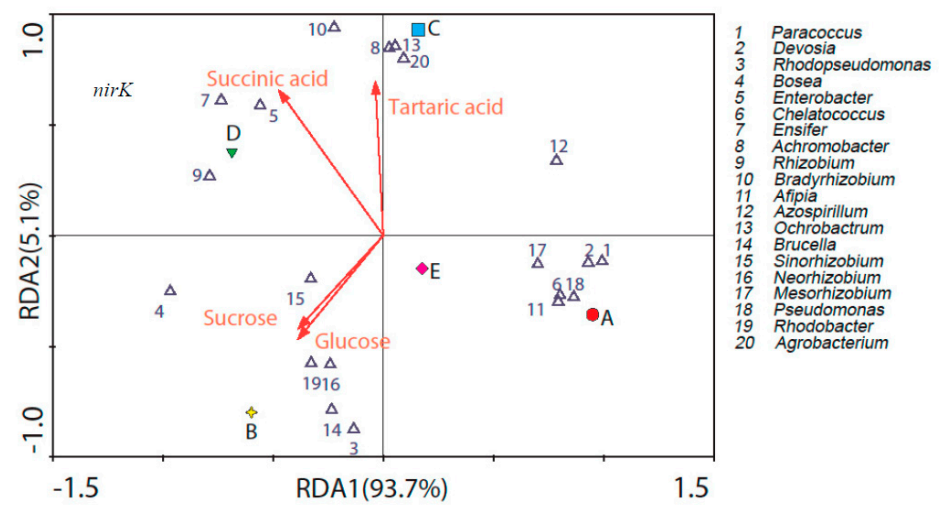

(A)

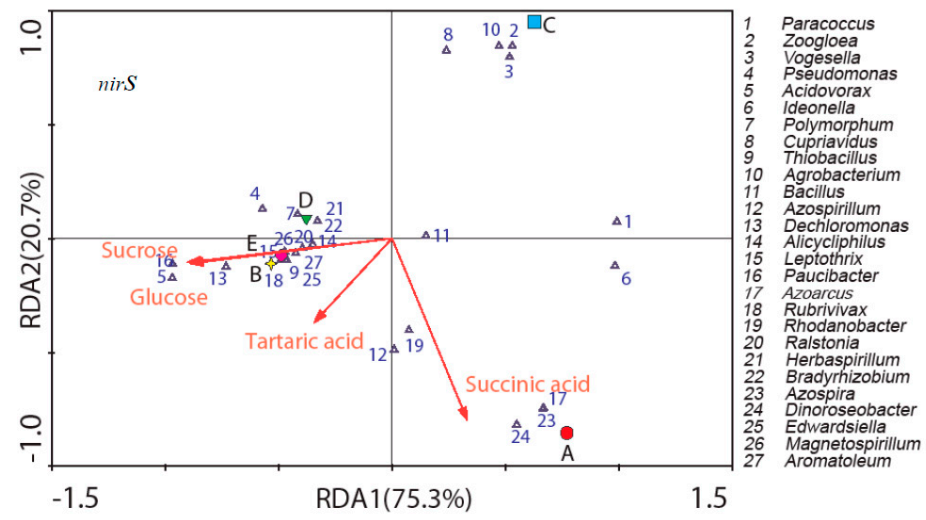

(B)

Figure 4. RDA analysis for the relationships between relative abundances of denitrifying bacteria and exudates: (A) RDA1 93.7\% and RDA2 5.1\%; (B) RDA1 75.3\% and RDA2 20.7\%. Color marks and colorless marks indicate different treatments and different denitrifying bacteria, respectively; vectors indicate the magnitude and direction of correlation between LMWC substrates and composition of denitrifying bacteria community; the angle between the microbes and vectors expresses positive and negative correlations between microbes and artificial exudates (acute angles express positive correlation; obtuse angle, negative correlation; right angles, no correlation). $\mathrm{A}=\mathrm{Con}$; $\mathrm{B}=\mathrm{ARE}$; $\mathrm{C}=\mathrm{Glu}(-) ; \mathrm{D}=\operatorname{Org}(-) ; \mathrm{E}=\operatorname{Ami}(-)$. 


\section{Discussion}

In CWs, there are many kinds of plants, which release lots of exudates and modify their rhizospheric environment [15]. The aim of this research was to determine the effects of exudate compounds on microbial $\mathrm{N}$ removal in CWs. $\mathrm{N}$ removal efficiency was measured to illuminate the function of denitrifying bacteria. Our study demonstrates that removal efficiency for TN in exudate-treated groups was significantly higher than for control groups, suggesting that artificial root exudates act as a $\mathrm{C}$ source to promote $\mathrm{N}$ removal. Moreover, in contrast to the other treatments, the Ami(-)-treated group had the highest removal efficiency for N. N is a key element for biosynthesis, and the availability of amino acids is of prime importance since these molecules are directly incorporated in metabolic pathways [22]. The presence of amino acids may affect the use of $\mathrm{NO}_{3}{ }^{-}-\mathrm{N}$ by microorganisms, and amino acids may have special functions in the denitrification. The role of amino acids in denitrification in CW should be the subject of future study.

In this study, the more exudate ingredients are present, the higher the microbial abundance. The Ami(-)-treated group had moderate gene abundance but the fastest removal efficiency of $\mathrm{N}$ pollutant. This result contrasts with previous studies showing that microbial abundance is more likely to be correlated with potential microbial activity [23,24]. However, Shrewsbury et al. [25] reported that environmental variables had an influence on denitrification rates and were a more important driver than denitrifying bacteria abundance; that study also suggested that nutrient availability was likely the most suitable predictor of denitrification rates. This may explain our results for the Ami(-)-treated group, in which although denitrifying bacteria had moderate gene abundance, the microbial community was suitable to the environment and conducive to $\mathrm{N}$ removal.

Although the dominant genera shared similarities in all treatments, the relative abundance of genera varied with the addition of LMWC substrates. This difference could indicate that some microbial communities may be more functionally plastic, taking advantage of changes when organic substrates were added, while others are more functionally resistant. We also found that organic acids significantly affected nirK gene abundance while soluble sugars seemed to be more important to nirS gene abundance. However, we noted that the same $\mathrm{C}$ concentration of artificial exudates led to similar $\mathrm{NO}_{3}{ }^{-}-\mathrm{N}$ removal efficiency, except for Ami(-), indicating that variations of $\mathrm{C}$ source had no significant effect on $\mathrm{NO}_{3}{ }^{-}-\mathrm{N}$ removal. There is evidence that plants actively select specific elements of their bacterial rhizospheric microflora [26-28]; hence, we speculate that microbial abundance and community jointly affected $\mathrm{N}$ removal, and that total organic $\mathrm{C}$ is the main factor influencing the denitrification. In the construction of CWs, plants that secrete more organic $\mathrm{C}$ should be prioritized.

Distinct changes in bacterial communities in CWs amended with artificial exudates were revealed by Illumina high-throughput sequencing. These results indicate the potential importance of LMWC compounds in influencing the structure of bacterial communities, in general agreement with other studies [22,29]. Some genera in our study responded positively to the artificial exudates; this result confirms previous studies suggesting that the most common sugars, organic acids, and amino acids associated with root exudate to rhizosphere are nutrient sources, chemoattractant signals, and promoters for microbial growth [30]. Interestingly, a small percentage of genera in our study responded negatively to the artificial exudates. Michalet et al. [31] suggested that a negative impact may result from the direct inhibition of microorganisms due to the presence of particular compounds. In our study, artificial exudates were the most common $C$ substrates, which are often used as $C$ sources for microorganisms; hence this negative impact was more likely given that some genera were outcompeted by the rapid growth of other microorganisms better able to adapt to the environment [32].

The microbial communities were changed by the added artificial exudates, but there was no significant relationship between $C$ substrates and bacterial community composition $(p>0.05$ by Monte Carlo permutation test). There are three possible reasons for this nonsignificance. Firstly, substrate use efficiencies likely vary across substrates; for example, sucrose converted to glucose by microbial metabolism would mean that the actual amount of glucose was more than the amount of inflow. Secondly, some substrates may have been catabolized with no apparent net microbial biomass 
accumulation. Thirdly, some genera may have increased equally in response to the addition of certain substrates, so that relative shifts in community composition would be undetectable [33].

Furthermore, the degradation efficiency of four substrates varied with substrate combination. Tartaric acid and glucose were the dominant $C$ sources for microbial denitrification. The redox properties of organic acid are influenced by its own structure and functional groups. Tartaric acid contains two $\alpha-\mathrm{OH}$ functional groups: hydroxyl $(-\mathrm{OH})$ belongs to the electron-donating group. Succinic acid has only two carboxyl $(-\mathrm{COOH})$ groups, which are strong electron-withdrawing groups. In the process of denitrification, $\mathrm{NO}_{3}{ }^{-}-\mathrm{N}$ reduction needs electrons. This may be the reason that tartaric acid was more utilized as a denitrifying microbial $\mathrm{C}$ source and more degraded. Sucrose converts to glucose in the path of microbe metabolism, and glucose degradation included the transformation of sucrose. Our glucose degradation rate was actually higher than the expected degradation rate, so glucose had a higher utilization than sucrose in denitrifying microorganism metabolism. These results may thus be of use in reflecting the ability of $C$ substrates to metabolize via microbes; the choice of easy degradation substrates should be a priority in experiments adding $C$ sources.

We did observe significant $\mathrm{N}$ removal in response to the addition of artificial exudates. It is important to note that, in order to achieve rapid responses of microorganisms, the concentrations of added LMWC were relatively high, although in natural water bodies, both $\mathrm{N}$ and $\mathrm{C}$ pollutants occur at relatively low concentrations (typically less than $10 \mathrm{mg} \mathrm{L}^{-1}$ ), and the highest removal of TN often occurs at a $\mathrm{C} / \mathrm{N}$ ratio of 5-7 [34] - so longer-term responses observed under field conditions may not equate with the shorter-term responses observed here. In the early stages of wetland operation, plant growth is not sufficient to provide a $C$ source for microorganisms, therefore, we may add artificial exudates to wetlands to facilitate the startup. Further work is required to determine how these LMWC compounds may alter microbial communities of denitrifying bacteria using lower concentrations. Furthermore, sugars and organic acids are only a fraction of the exudate constituents of aquatic species. In the future, many more chemical constituents (for example, phenolic compounds, flavonoids, and alkaloids) that derive from exudates of land plants should be studied in aquatic plants.

\section{Conclusions}

LMWC substrates promoted $\mathrm{N}$ removal in CWs. Organic acids and soluble sugars increased $\mathrm{N}$ removal while amino acids were negative to $\mathrm{N}$ removal. Total organic $\mathrm{C}$ was the main factor influencing the denitrification; artificial exudates (organic acids, soluble sugars, amino acids) induced variations in abundances and affected the microbial community composition of denitrifying bacteria, although there was no significant relationship between LMWC compounds and bacterial community composition.

In summary, we suggest that although the ways that community structures of denitrifying bacteria respond to exudate addition as a complex ecological process is an open question, there is promise for $\mathrm{N}$ removal in response to exudate additions across LMWC types.

Acknowledgments: The authors are grateful for the financial support from the Major Science and Technology Program for Water Pollution Control and Treatment (NO. 2014ZX07303-003-11 and 2012ZX07105-003).

Author Contributions: Xinze Wang and Hailu Wu conceived and designed the experiments; Hailu Wu performed the experiments; Xiaojuan He analyzed the data; Xiaojuan He and Hailu Wu wrote the paper; Xinze Wang reviewed and edited the paper.

Conflicts of Interest: The authors declare no conflict of interest.

\section{References}

1. Anderson, D.M.; Glibert, P.M.; Burkholder, J.M. Harmful algal blooms and eutrophication: Nutrient sources, composition, and consequences. Estuaries 2002, 25, 704-726. [CrossRef]

2. Liu, D.; Ge, Y.; Chang, J.; Peng, C.; Gu, B.; Chan, G.Y.S.; Wu, X. Constructed wetlands in China: Recent developments and future challenges. Front. Ecol. Environ. 2009, 7, 261-268. [CrossRef]

3. Vymazal, J. Removal of nutrients in various types of constructed wetlands. Sci. Total Environ. 2007, 380, 48-65. [CrossRef] [PubMed] 
4. Ding, Y.; Song, X.; Wang, Y.; Yan, D. Effects of dissolved oxygen and influent COD/N ratios on nitrogen removal in horizontal subsurface flow constructed wetland. Ecol. Eng. 2012, 46, 107-111. [CrossRef]

5. Fan, J.; Wang, W.; Zhang, B.; Guo, Y.; Ngo, H.H.; Guo, W.; Zhang, J.; Wu, H. Nitrogen removal in intermittently aerated vertical flow constructed wetlands: Impact of influent COD/N ratios. Bioresour. Technol. 2013, 143, 461-466. [CrossRef] [PubMed]

6. Yuan, Y.; Liu, J.; Ma, B.; Liu, Y.; Wang, B.; Peng, Y. Improving municipal wastewater nitrogen and phosphorous removal by feeding sludge fermentation products to sequencing batch reactor (SBR). Bioresour. Technol. 2016, 222, 326-334. [CrossRef] [PubMed]

7. Torresi, E.; Casas, M.E.; Polesel, F.; Plosz, B.G.; Christensson, M.; Bester, K. Impact of external carbon dose on the removal of micropollutants using methanol and ethanol in post-denitrifying Moving Bed Biofilm Reactors. Water Res. 2017, 108, 95-105. [CrossRef] [PubMed]

8. Zhai, X.; Piwpuan, N.; Arias, C.A.; Headley, T.; Brix, H. Can root exudates from emergent wetland plants fuel denitrification in subsurface flow constructed wetland systems? Ecol. Eng. 2013, 61, 555-563. [CrossRef]

9. Zhao, C.; Xie, H.; Xu, J.; Xu, X.; Zhang, J.; Hu, Z.; Liu, C.; Liang, S.; Wang, Q.; Wang, J. Bacterial community variation and microbial mechanism of triclosan (TCS) removal by constructed wetlands with different types of plants. Sci. Total Environ. 2015, 505, 633-639. [CrossRef] [PubMed]

10. Meng, P.; Hu, W.; Pei, H.; Hou, Q.; Ji, Y. Effect of different plant species on nutrient removal and rhizospheric microorganisms distribution in horizontal-flow constructed wetlands. Environ. Technol. 2014, 35, 808-816. [CrossRef] [PubMed]

11. Salvato, M.; Borin, M.; Doni, S.; Macci, C.; Ceccanti, B.; Marinari, S.; Masciandaro, G. Wetland plants, micro-organisms and enzymatic activities interrelations in treating N polluted water. Ecol. Eng. 2012, 47, 36-43. [CrossRef]

12. Huang, X.F.; Chaparro, J.M.; Reardon, K.F.; Zhang, R.; Shen, Q.; Vivanco, J.M. Rhizosphere interactions: Root exudates, microbes, and microbial communities. Botany-Botanique 2014, 92, 267-275. [CrossRef]

13. Osaka, T.; Shirotani, K.; Yoshie, S.; Tsuneda, S. Effects of carbon source on denitrification efficiency and microbial community structure in a saline wastewater treatment process. Water Res. 2008, 42, 3709-3718. [CrossRef] [PubMed]

14. Xie, X.M.; Liao, M.; Yang, J.; Chai, J.J.; Fang, S.; Wang, R.H. Influence of root-exudates concentration on pyrene degradation and soil microbial characteristics in pyrene contaminated soil. Chemosphere 2012, 88, 1190-1195. [CrossRef] [PubMed]

15. Bais, H.P.; Weir, T.L.; Perry, L.G.; Gilroy, S.; Vivanco, J.M. The role of root exudates in rhizosphere interations with plants and other organisms. Annu. Rev. Plant Biol. 2006, 57, 233-266. [CrossRef] [PubMed]

16. Wu, H.L.; Wang, X.Z.; He, X.J.; Zhang, S.B.; Liang, R.B.; Shen, J. Effects of root exudates on denitrifier gene abundance, community structure and activity in a micro-polluted constructed wetland. Sci. Total Environ. 2017, 598, 697-703. [CrossRef] [PubMed]

17. Wu, H.; Xu, K.Q.; He, X.J.; Wang, X.Z. Removal of Nitrogen by Three Plant Species in Hydroponic Culture: Plant Uptake and Microbial Degradation. Water Air Soil Pollut. 2016, 227, 324. [CrossRef]

18. Di, H.J.; Cameron, K.C.; Shen, J.P.; Winefield, C.S.; O'Callaghan, M.; Bowatte, S.; He, J.Z. Ammonia-oxidizing bacteria and archaea grow under contrasting soil nitrogen conditions. FEMS Microbiol. Ecol. 2010, 72, 386-394. [CrossRef] [PubMed]

19. Edgar, R.C.; Haas, B.J.; Clemente, J.C.; Quince, C.; Knight, R. UCHIME improves sensitivity and speed of chimera detection. Bioinformatics 2011, 27, 2194-2200. [CrossRef] [PubMed]

20. Mothur Analysis. Available online: https://www.mothur.org/ (accessed on 12 June 2017).

21. Valentin-Vargas, A.; Root, R.A.; Neilson, J.W.; Chorover, J.; Maier, R.M. Environmental factors influencing the structural dynamics of soil microbial communities during assisted phytostabilization of acid-generating mine tailings: A mesocosm experiment. Sci. Total Environ. 2014, 500, 314-324. [CrossRef] [PubMed]

22. Baudoin, E.; Benizri, E.; Guckert, A. Impact of artificial root exudates on the bacterial community structure in bulk soil and maize rhizosphere. Soil Biol. Biochem. 2003, 35, 1183-1192. [CrossRef]

23. Jones, C.M.; Spor, A.; Brennan, F.P.; Breuil, M.C.; Bru, D.; Lemanceau, P.; Griffiths, B.; Hallin, S.; Philippot, L. Recently identified microbial guild mediates soil $\mathrm{N}_{2} \mathrm{O}$ sink capacity. Nat. Clim. Chang. 2014, 4, 801-805. [CrossRef] 
24. Hallin, S.; Hellman, M.; Choudhury, M.I.; Ecke, F. Relative importance of plant uptake and plant associated denitrification for removal of nitrogen from mine drainage in sub-arctic wetlands. Water Res. 2015, 85, 377-383. [CrossRef] [PubMed]

25. Shrewsbury, L.H.; Smith, J.L.; Huggins, D.R.; Carpenter-Boggs, L.; Reardon, C.L. Denitrifier abundance has a greater influence on denitrification rates at larger landscape scales but is a lesser driver than environmental variables. Soil Biol. Biochem. 2016, 103, 221-231. [CrossRef]

26. Broeckling, C.D.; Broz, A.K.; Bergelson, J.; Manter, D.K.; Vivanco, J.M. Root exudates regulate soil fungal community composition and diversty. Appl. Environ. Microbiol. 2008, 74, 738-744. [CrossRef] [PubMed]

27. Houlden, A.; Timms-Wilson, T.M.; Day, M.J.; Bailey, M.J. Influence of plant developmental stage on microbial community structure and activity in the rhizosphere of three field crops. FEMS Microbiol. Ecol. 2008, 65, 193-201. [CrossRef] [PubMed]

28. Rudrappa, T.; Czymmek, K.J.; Pare, P.W.; Bais, H.P. Root-Secreted Malic Acid Recruits Beneficial Soil Bacteria. Plant Physiol. 2008, 148, 1547-1556. [CrossRef] [PubMed]

29. Huang, H.; Wang, S.; Lv, J.; Xu, X.; Zhang, S. Influences of artificial root exudate components on the behaviors of BDE-28 and BDE-47 in soils: Desorption, availability, and biodegradation. Environ. Sci. Pollut. Res. 2016, 23, 7702-7711. [CrossRef] [PubMed]

30. Haichar, F.Z.; Santaella, C.; Heulin, T.; Achouak, W. Root exudates mediated interactions belowground. Soil Biol. Biochem. 2014, 77, 69-80. [CrossRef]

31. Michalet, S.; Rohr, J.; Warshan, D.; Bardon, C.; Rogy, J.C.; Domenach, A.M.; Czarnes, S.; Pommier, T.; Combourieu, B.; Guillaumaud, N.; et al. Phytochemical analysis of mature tree root exudates in situ and their role in shaping soil microbial communities in relation to tree $\mathrm{N}$-acquisition strategy. Plant Physiol. Biochem. 2013, 72, 169-177. [CrossRef] [PubMed]

32. Shi, S.; Richardson, A.E.; O'Callaghan, M.; DeAngelis, K.M.; Jones, E.E.; Stewart, A.; Firestone, M.K.; Condron, L.M. Effects of selected root exudate components on soil bacterial communities. FEMS Microbiol. Ecol. 2011, 77, 600-610. [CrossRef] [PubMed]

33. Eilers, K.G.; Lauber, C.L.; Knight, R.; Fierer, N. Shifts in bacterial community structure associated with inputs of low molecular weight carbon compounds to soil. Soil Biol. Biochem. 2010, 42, 896-903. [CrossRef]

34. Torrijos, V.; Gonzalo, O.G.; Trueba-Santiso, A.; Ruiz, I.; Soto, M. Effect of by-pass and effluent recirculation on nitrogen removal in hybrid constructed wetlands for domestic and industrial wastewater treatment. Water Res. 2016, 103, 92-100. [CrossRef] [PubMed] 